\title{
Sorafenib administered using a high-dose, pulsatile regimen in patients with advanced solid malignancies: a phase I exposure escalation study
}

\author{
L. H. Mammatas ${ }^{1} \cdot$ A. S. Zandvliet ${ }^{2} \cdot$ M. Rovithi ${ }^{1} \cdot$ R. J. Honeywell ${ }^{1} \cdot$ E. L. Swart ${ }^{2} \cdot$ G. J. Peters ${ }^{1,3}$. $^{2}$ \\ C. W. Menke-van der Houven van Oordt ${ }^{1}$ H. M. W. Verheul ${ }^{1,4}$
}

Received: 6 December 2019 / Accepted: 24 March 2020 / Published online: 9 April 2020

(c) The Author(s) 2020

\begin{abstract}
Background (Pre)clinical evidence is accumulating that intermittent exposure to increased doses of protein kinase inhibitors may improve their treatment benefit. In this phase I trial, the safety of high-dose, pulsatile sorafenib was studied.

Patients and methods High-dose sorafenib was administered once weekly in exposure escalation cohorts according to a $3+3$ design. Drug monitoring was performed in weeks 1-3 and doses were adjusted to achieve a predefined target plasma area under the curve (AUC)(0-12 h). The effect of low gastric $\mathrm{pH}$ on improving sorafenib exposure was investigated by intake of the acidic beverage cola.

Results Seventeen patients with advanced malignancies without standard treatment options were included. Once weekly, high-dose sorafenib exposure was escalated up to a target AUC $(0-12 \mathrm{~h})$ of $125-150 \mathrm{mg} / \mathrm{L} / \mathrm{h}$, achieving a twofold higher $C_{\max }$ compared to standard continuous dosing. Dose-limiting toxicity was observed in three patients: grade 3 duodenal perforation (2800 $\mathrm{mg}$ sorafenib), grade 5 multiorgan failure ( $2800 \mathrm{mg}$ sorafenib) and grade 5 biliary tract perforation ( $3600 \mathrm{mg}$ sorafenib). The mean difference between observed and target $\mathrm{AUC}(0-12 \mathrm{~h})$ was $45 \%(\mathrm{SD} \pm 56 \%)$ in week 1 using a fixed starting dose of sorafenib compared to $2 \%$ ( $\mathrm{SD} \pm 32 \%$ ) in week 3 as a result of drug monitoring $(P=0.06)$. Dissolving sorafenib in cola, instead of water, did not improve sorafenib exposure. Clinical benefit with stable disease as the best response was observed in two patients.

Conclusion Treatment with high-dose, once weekly sorafenib administration resulted in dose-limiting toxicity precluding dose escalation above the exposure cohort of $125-150 \mathrm{mg} / \mathrm{L} / \mathrm{h}$. Drug monitoring was a successful strategy to pursue a target exposure.
\end{abstract}

Keywords Sorafenib $\cdot$ Phase I clinical trial $\cdot$ High dose $\cdot$ Pulsatile $\cdot$ Drug monitoring $\cdot$ Cola

Electronic supplementary material The online version of this article (https://doi.org/10.1007/s00280-020-04065-5) contains supplementary material, which is available to authorized users.

H. M. W. Verheul

Henk.verheul@radboudumc.nl

1 Department of Medical Oncology, Cancer Center Amsterdam, Amsterdam UMC, VUmc University Medical Center Amsterdam, Amsterdam, The Netherlands

2 Department of Clinical Pharmacology and Pharmacy, Cancer Center Amsterdam, Amsterdam UMC, VUmc University Medical Center Amsterdam, Amsterdam, The Netherlands

\section{Introduction}

Sorafenib is an oral multikinase inhibitor, originally developed as an inhibitor of RAF kinases [1]. Besides activity against C-RAF, B-RAF and mutant B-RAF, it also inhibits vascular endothelial growth factor receptors 1,2 and

3 Department of Biochemistry, Medical University of Gdansk, Gdansk, Poland

4 Department of Medical Oncology, Radboud University Medical Center, Geert Grooteplein Zuid 8, Internal postal code 452, P.O. Box 9101, 6500 HB Nijmegen, The Netherlands 
3 , platelet-derived growth factor receptor $\beta$, FMS-like tyrosine kinase 3, c-Kit protein and RET receptor tyrosine kinase at low concentrations [2]. At high intracellular concentrations, sorafenib has affinity for multiple other kinases [3]. Sorafenib is currently approved for the treatment of renal cell carcinoma, hepatocellular carcinoma and iodine refractory thyroid cancer at a standard fixed dose of $400 \mathrm{mg}$ twice daily in a continuous schedule [4-7]. However, at this standard fixed dose large interpatient variability in drug exposure was demonstrated after both single and multiple doses [8].

Increased sorafenib exposure is associated with improved efficacy $[9,10]$. Dose escalation of sorafenib to $600 \mathrm{mg}$ twice daily after failure of standard dosing in patients with progressive renal cell carcinoma resulted in tumor reduction in $42 \%$ of the patients [9]. In addition, intrapatient dose escalation in patients without substantial toxicity showed that a higher area under the concentration-time curve $\left(\mathrm{AUC}_{\max }>100 \mathrm{mg} / \mathrm{L} / \mathrm{h}\right.$ ) of sorafenib was associated with longer progression-free survival (PFS) [10]. Unfortunately, toxicity limits further dose escalation of the continuous schedule [8].

An alternative approach to achieve high exposure, with less toxicity, may be high-dose, pulsatile administration of protein kinase inhibitors $[11,12]$. Recently, we showed promising preclinical and clinical benefit of an alternative high-dose treatment regimen of sunitinib [13]. Also, promising preclinical results for high-dose sorafenib were reported. In mice bearing 789-O renal cell carcinoma xenografts, such a schedule exhibited increased reduction of tumor perfusion and microvessel density as well as slower tumor growth in comparison to continuous conventional dosing [14].

An important challenge for optimizing high-dose sorafenib administration is the amount of drug absorption in the gastrointestinal tract. Sorafenib absorption is saturable > $800 \mathrm{mg} /$ day in a daily continuous schedule. However, a moderate fat meal (in comparison to a high fat meal of $\geq 50 \%$ fat) and multiple divided doses per day have been shown to improve the absorption of sorafenib by $30 \%$ and $50 \%$, respectively $[15,16]$. The influence of gastric $\mathrm{pH}$ on the absorption of sorafenib is less clear, although the solubility of sorafenib increases with decreasing $\mathrm{pH}$ and ranges from $0.034 \mathrm{mg} / 100 \mathrm{~mL}$ at $\mathrm{pH} 1.0$ to $0.013 \mathrm{mg} / 100 \mathrm{~mL}$ at $\mathrm{pH} 4.5$ [17-19]. Thus, the administration of an acidic beverage such as classic cola, with a $\mathrm{pH}$ of 2.5 , could potentially improve sorafenib absorption and bioavailability [20,21].

Based on these considerations, we initiated a clinical phase I study with high-dose, pulsatile sorafenib. Weekly pulses of high sorafenib exposure over a 12-h window [AUC $(0-12 \mathrm{~h})]$ were pursued in an attempt to improve clinical efficacy. To overcome saturation of absorption, we applied dose fractioning (portions of $200-400 \mathrm{mg}$ administered at $2 \mathrm{~h}$ intervals), a standardized moderate fat diet, and investigated the effect of cola on sorafenib bioavailability. Sorafenib exposure was determined during $12 \mathrm{~h}$ following ingestion of the last dose fraction. Finally, administration of the same dose was anticipated to result in large variability in sorafenib plasma $\operatorname{AUC}(0-12 \mathrm{~h})$ per patient [8]. Therefore, drug monitoring was performed during weeks $1-3$ to titrate the patients' individual dose based on the sorafenib plasma $\mathrm{AUC}(0-12 \mathrm{~h})$ according to exposure escalation cohorts [22].

\section{Patients and methods}

\section{Patient selection}

Patients were eligible if they had a pathologically confirmed solid malignancy refractory to standard therapy or if no standard therapy existed for them. Patients had to be $\geq 18$ years of age with an Eastern Cooperative Oncology Group Performance of $\leq 1$. Required laboratory values at entry included hemoglobin $\geq 5.6 \mathrm{mmol} / \mathrm{L}$, absolute neutrophil count $\geq 1.5 \times 10^{9} / 1$, platelet count $\geq 100 \times 10^{9} /$, total bilirubin $\leq 1.5$ times the upper limit of normal (ULN), ALT and AST $\leq 2.5 \times$ ULN (in case of liver metastases: $\leq 5$ times ULN), serum creatinine $\leq 1.5 \times$ ULN or creatinine clearance $\geq 50 \mathrm{ml} / \mathrm{min}$ (based on MDRD), albumin $>25 \mathrm{~g} / \mathrm{L}, \mathrm{PT}$-INR/PTT $<1.5 \times \mathrm{ULN}$ (unless coumarin derivatives were used), and activated partial thromboplastin time $<1.25 \times$ ULN.

The main exclusion criteria were other anticancer therapies within 4 weeks ( 6 weeks for nitrosoureas and mitomycin C); evidence of serious uncontrolled concomitant disease (such as cardiovascular disease, nervous system disease, pulmonary disease, gastrointestinal disorders or active bacterial, viral, fungal or mycobacterial infections); uncontrollable hypertension ( $>160 / 95 \mathrm{mmHg}$ ); prior radiotherapy on the abdominal or thoracic area or on $>3$ vertebrae; major surgery within 4 weeks; pregnancy or breast feeding. If applicable, patients were required to take contraceptive precautions while on the trial and for 6 months afterwards.

All patients gave written informed consent before study entry and the local medical ethics committee of the Amsterdam UMC, location VUmc (Medisch Ethische Toetsingscommissie VUmc), approved the study. The study (NCT02636426) was conducted in accordance with the Declaration of Helsinki and Good Clinical Practice guidelines.

\section{Study design and treatment plan}

This single center phase I study was conducted at the Amsterdam UMC, location VUmc, the Netherlands. 
High-dose sorafenib was administered once weekly in exposure escalation cohorts that consisted of 3-6 patients using a standard $3+3$ design. Drug monitoring was performed in weeks 1-3 and doses were adjusted a maximum of two times if necessary to achieve the predefined target plasma AUC $(0-12 \mathrm{~h})$ of the cohort. The starting exposure level was $25-50 \mathrm{mg} / \mathrm{L} / \mathrm{h}$, analogous to the continuous schedule [23], and was escalated in subsequent cohorts with increments of $25 \mathrm{mg} / \mathrm{L} / \mathrm{h}$.

The primary objective was to investigate the maximum tolerated plasma $\operatorname{AUC}(0-12 \mathrm{~h})$ of high-dose, pulsatile sorafenib and its safety and tolerability. Secondary objectives were (1) the pharmacokinetic behavior, (2) the influence of cola on sorafenib exposure, (3) the feasibility of drug monitoring to achieve the target plasma AUC $(0-12 \mathrm{~h})$, and (4) preliminary evidence of improved anticancer activity with high-dose pulsatile sorafenib treatment of this alternative sorafenib treatment strategy.

The total weekly dose sorafenib was divided in portions of 200-400 $\mathrm{mg}$ and given every $2 \mathrm{~h}$ to prevent saturation of absorption and to result in a high plasma peak concentration at the end of all ingested portions. Each dose was dissolved in either a large glass of water or classic Coca-Cola (the Coca-Cola Company, Atlanta GA) ( $240 \mathrm{ml})$. Furthermore, patients used a standard low-fat diet $( \pm 14 \mathrm{~g}$ fats, $100 \mathrm{~g}$ proteins, $1800 \mathrm{kcal}$ ) with as well as between doses on the day of administration to optimize the absorption and bioavailability of sorafenib.

Patients continued study treatment until unacceptable toxicity, disease progression or the patient's request to stop. Evaluable patients had to be treated for a minimum of 2 weeks or would otherwise be replaced by an additional patient.

\section{Safety assessment}

Safety and tolerability assessments, including physical examination, ECG and blood hematology and chemistry, were performed weekly during the first 8 weeks and once every 4 weeks thereafter. Adverse events (AEs) were graded according to the National Cancer Institute Common Terminology Criteria for Adverse Events version 4.0.

Dose (/exposure)-limiting toxicity (DLT) was defined as any grade 3 toxicity that occurred within the first 6 weeks of treatment and possibly related to the study drug. The maximum tolerated exposure (MTE) was defined at the highest exposure level at which $\leq 33 \%$ of patients experienced DLTs.

\section{Tumor response measurements}

Tumor response was assessed by computed tomography or magnetic resonance imaging at baseline and every 8 weeks thereafter using RECIST version 1.1 [24].

\section{Pharmacokinetic analysis}

During the first 3 weeks of study treatment, blood samples for measurement of sorafenib and its active metabolite sorafenib $\mathrm{N}$-oxide were taken prior to each dose (i.e. prior to each portion of the total weekly dose given every $2 \mathrm{~h}$ ) and $1,2,3,4,8,12$ and 60-96 $\mathrm{h}$ after the last dose.

The plasma concentrations of sorafenib and sorafenib $\mathrm{N}$-oxide were determined using a validated liquid chromatography-tandem mass spectrometry method [25]. The sorafenib and sorafenib $\mathrm{N}$-oxide plasma $\operatorname{AUC}(0-12 \mathrm{~h})$ were determined from the time of the last sorafenib tablet ingestion until $12 \mathrm{~h}$ afterwards with a non-compartmental method. Within $72 \mathrm{~h}$ after ingestion, the sorafenib AUC $(0-12 \mathrm{~h})$ was established by our department of Clinical Pharmacology and Pharmacy and if necessary the dose was adjusted accordingly to achieve the target $\mathrm{AUC}(0-12 \mathrm{~h})$ of the exposure cohort. Per patient a maximum of two dose adjustments were permitted. In addition, the maximum concentration $\left(\mathrm{C}_{\max }\right)$ and time of maximum concentration $\left(T_{\max }\right)$ were determined.

\section{Statistical considerations}

Descriptive statistics were used to describe patient characteristics, treatment administration, safety, efficacy and pharmacokinetic data. Progression-free survival (PFS) was defined as the time from first treatment until progression of disease or death as a result of any cause. Fisher's exact tests were used to assess correlations between exposure level or dose and frequency of AEs. A paired $t$ test was used to investigate the effect of personalized dose titration on achieving the target sorafenib AUC $(0-12 \mathrm{~h})$. Last, a Mann-Whitney test was used to investigate the effect of cola on dose normalized (to a standard dose of $800 \mathrm{mg}$ sorafenib) plasma sorafenib $C_{\max }$ and $\operatorname{AUC}(0-12 \mathrm{~h})$ levels. Data were considered significant at $P<0.05$.

\section{Results}

\section{Patients and treatment}

Seventeen patients with progressive metastatic malignancies were enrolled between November 2015 and December 2017. Patient characteristics are shown in Table 1. A total number 
Table 1 Patient characteristics

\begin{tabular}{ll}
\hline Characteristic & Number of patients, $N=17$ \\
\hline $\begin{array}{l}\text { Age (years) } \\
\text { Median (range) }\end{array}$ & $61(26-74)$ \\
Gender & $7 / 10$ \\
Males/females & \\
ECOG performance status & $2 / 15$ \\
0/1 & \\
Tumor type & 2 \\
Pancreas & 2 \\
Bile duct & 2 \\
Head and neck & 2 \\
Esophagus & 2 \\
Colorectal & 1 \\
Kidney & 1 \\
Liver (HCC) & 1 \\
Melanoma & 1 \\
Uterus & 1 \\
Breast & 1 \\
Sarcoma & 1 \\
Metaplastic carcinoma & \\
Prior treatment & 8 \\
Surgery & 6 \\
Radiotherapy & 13 \\
Chemotherapy & 3 standard dose sorafenib) \\
Protein kinase inhibitor & \\
Number of prior systemic regimens & $2(0-6)$ \\
Median (range) & \\
\hline
\end{tabular}

of 114 weekly cycles of sorafenib were administered with a median of 7 cycles per patient (range 1-24).

Patients were treated at target $\mathrm{AUC}(0-12 \mathrm{~h})$ levels from 25-50 to $125-150 \mathrm{mg} / \mathrm{L} / \mathrm{h}$. Because the first exposure cohort [AUC $(0-12 \mathrm{~h}) 25-50 \mathrm{mg} / \mathrm{L} / \mathrm{h}$ ] already resulted in higher sorafenib exposure than expected [median AUC(0-12 h) 71, range $61-103 \mathrm{mg} / \mathrm{L} / \mathrm{h}$ ], the second exposure cohort was set at $75-100 \mathrm{mg} / \mathrm{L} / \mathrm{h}$. In subsequent cohorts, target exposure levels were increased with steps of $25 \mathrm{mg} / \mathrm{L} / \mathrm{h}$.

Reasons for treatment discontinuation were disease progression $(N=11)$, treatment-related toxicity $(N=3)$, completion of the study protocol, i.e. treatment discontinuation because $\geq 33 \%$ of patients experienced DLTs in that cohort $(N=1)$, patient withdrawal $(N=1)$ and a pathological bone fracture $(N=1)$. The latter two patients were considered non-evaluable as described in the protocol, because they had only received 1 week of study treatment and were replaced.

\section{Safety}

Adverse events which were at least possibly related to highdose sorafenib are summarized in Table 2. Most common clinical toxicities were fatigue $(67 \%)$, nausea $(67 \%)$, vomiting $(53 \%)$ and diarrhea (27\%). These grade 1-2 toxicities typically started 1-2 days after sorafenib administration and were manageable with standard supportive care measures.
Serious adverse events were predominantly observed in the gastrointestinal tract. At the target exposure level of $75-100 \mathrm{mg} / \mathrm{L} / \mathrm{h}$, one patient developed grade 5 biliary tract perforation after three cycles of treatment (sorafenib dose was $3600 \mathrm{mg}$ with an observed $\mathrm{AUC}(0-12 \mathrm{~h})$ of $182 \mathrm{mg} / \mathrm{L} / \mathrm{h})$. The cohort was expanded to six evaluable patients, but no further DLT occurred. At the subsequent 100-125 mg/L/h target exposure level, three patients were treated without DLT. However, a DLT occurred in two out of three patients in the $125-150 \mathrm{mg} / \mathrm{L} / \mathrm{h}$ cohort. One patient developed grade 3 duodenal perforation after two cycles of treatment (sorafenib dose was $2800 \mathrm{mg}$ with an observed AUC(0-12 h) of $54 \mathrm{mg} / \mathrm{L} / \mathrm{h})$. The other patient suffered from grade 5 multiorgan failure after two cycles of treatment (sorafenib dose was $2800 \mathrm{mg}$ with an observed AUC $(0-12 \mathrm{~h})$ of $47 \mathrm{mg} / \mathrm{L} / \mathrm{h})$ and died. At that point, the phase I study was preliminary terminated because these serious toxicities precluded further dose escalation and investigation of a potential benefit of a high-dose, pulsatile approach.

Overall, the frequency and rate of grade $\geq 3$ AEs increased with a higher dose of sorafenib $(P=0.003$ and $P=0.008$, respectively) but did not increase with higher exposure ( $P=0.43$ and $P=0.70$, respectively). Grade $\geq$ 3 AEs developed from doses $\geq 2800 \mathrm{mg} /$ week. Dose interruptions were required in five $(33 \%)$ patients, of which three $(20 \%)$ were due to the previously reported DLTs leading to permanent study discontinuation.

\section{Pharmacokinetics}

Plasma samples for pharmacokinetic analyses were available from all 17 included patients and results are summarized in Table 3. Mean exposure increased with higher sorafenib doses up to $2400 \mathrm{mg}$ per week, after which no additional increases were seen. This is possibly related to a saturation of uptake in the gastrointestinal tract. The increases were similar for $\operatorname{AUC}(0-12 \mathrm{~h})$ as well as $C_{\max }$ throughout the escalating exposure cohorts. In the current phase I study, highest exposure levels were up to $204 \mathrm{mg} / \mathrm{L} / \mathrm{h}(\mathrm{SD} \pm 113 \mathrm{mg} / \mathrm{L} / \mathrm{h})$ with a $C_{\max }$ up to $21.0 \mathrm{mg} / \mathrm{L}(\mathrm{SD} \pm 11 \mathrm{mg} / \mathrm{L})$, reached at median $7 \mathrm{~h}$ after ingestion (range 1-12 h). The plasma concentration time curves of sorafenib showed a biphasic pattern, which has been described previously, and is most likely caused by biliary excretion and the enterohepatic cycle (Fig. 1). No accumulation of sorafenib was seen a week after each ingestion. The major metabolite of sorafenib, sorafenib N-oxide, comprised approximately $4 \%$ of the parent drug and showed similar $C_{\max }$ and $\mathrm{AUC}(0-12 \mathrm{~h})$ patterns compared to sorafenib (Supplementary Figure S1). 


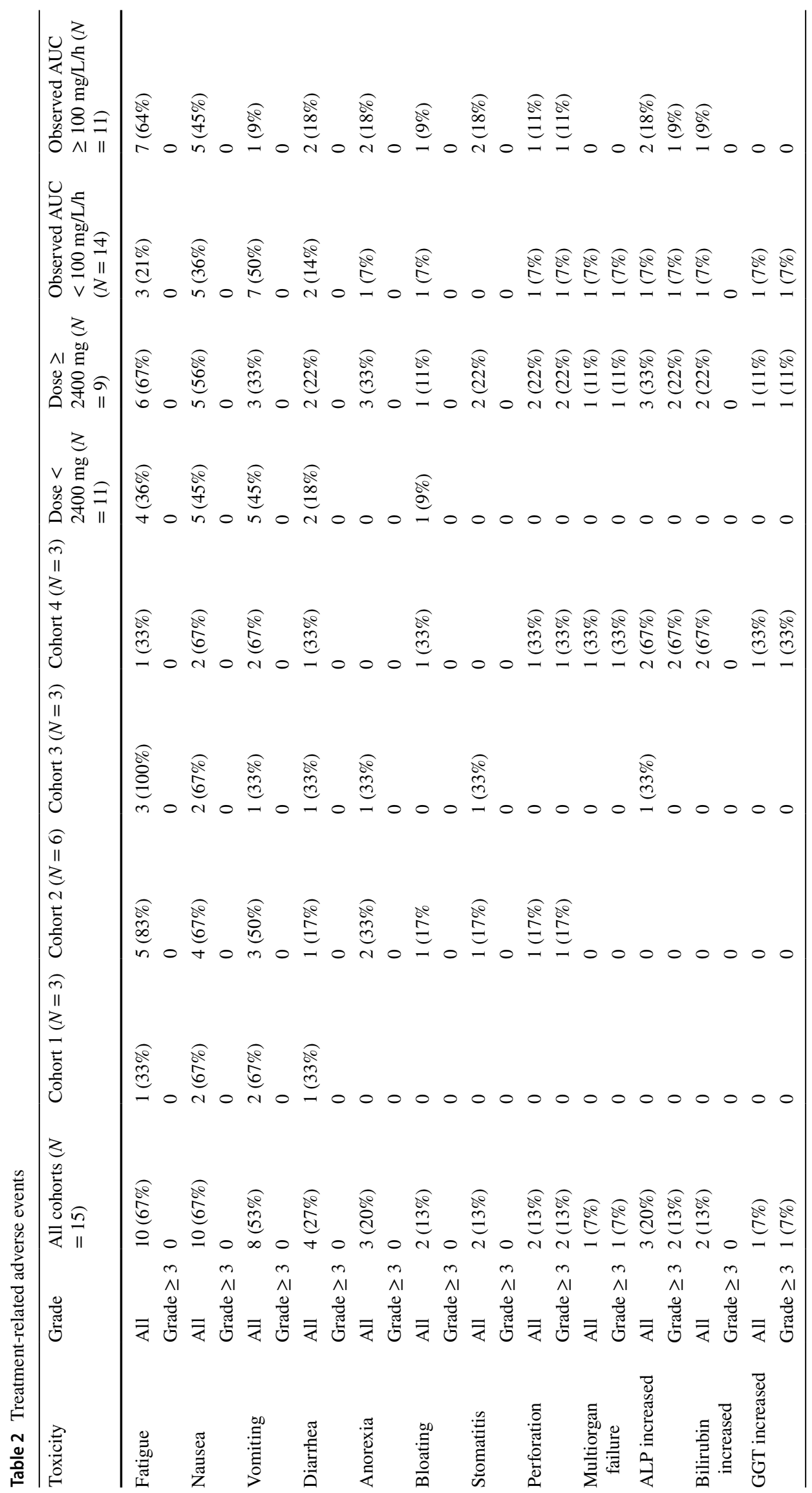


Table 3 Pharmacokinetic results for high-dose, pulsatile sorafenib

\begin{tabular}{|c|c|c|c|c|c|c|c|c|}
\hline Cohort & $\begin{array}{l}\text { No. of } \\
\text { patients }\end{array}$ & $\begin{array}{l}\text { Target } \\
\text { AUC }(0-12 \mathrm{~h}) \\
(\mathrm{mg} / \mathrm{L} / \mathrm{h})\end{array}$ & $\begin{array}{l}\text { Fixed dose } \\
\text { week } 1 \\
(\mathrm{mg})\end{array}$ & $\begin{array}{l}\text { PK-guided dose } \\
\text { week } 3(\mathrm{mg}) \text {, } \\
\text { mean }( \pm \mathrm{SD})\end{array}$ & $\begin{array}{l}\text { Observed } \\
\text { AUC }(0-12 \mathrm{~h}) \\
\text { week } 1(\mathrm{mg} / \mathrm{L} / \mathrm{h}) \text {, } \\
\text { mean }( \pm \mathrm{SD})\end{array}$ & $\begin{array}{l}\text { Observed } \\
\text { AUC }(0-12 \mathrm{~h}) \\
\text { week } 3(\mathrm{mg} / \mathrm{L} / \mathrm{h}) \text {, } \\
\text { mean }( \pm \mathrm{SD})\end{array}$ & $\begin{array}{l}C_{\max } \text { week } 1 \\
(\mu \mathrm{g} / \mathrm{L}), \text { mean } \\
( \pm \mathrm{SD})\end{array}$ & $\begin{array}{l}C_{\max } \text { week } 3 \\
(\mu \mathrm{g} / \mathrm{L}), \text { mean } \\
( \pm \mathrm{SD})\end{array}$ \\
\hline 1 & 3 & $25-50$ & 1000 & $533( \pm 306)$ & $78( \pm 22)$ & $31( \pm 13)$ & $9089( \pm 3281)$ & $4385( \pm 1312)$ \\
\hline 2 & 8 & $75-100$ & 2000 & $1867( \pm 993)$ & $125( \pm 59)$ & $102( \pm 49)$ & $13,696( \pm 5866)$ & $11,098( \pm 6115)$ \\
\hline 3 & 3 & $100-125$ & 2400 & $2333( \pm 219)$ & $204( \pm 113)$ & $96( \pm 40)$ & $20,829( \pm 11,234)$ & $13,280( \pm 5310)$ \\
\hline 4 & 3 & $125-150$ & 2800 & NA* & $120( \pm 13)$ & NA* & $15,200( \pm 1266)$ & NA* \\
\hline
\end{tabular}

*NA not applicable

At start of treatment, with a pulsatile fixed high-dose, sorafenib exposure showed large interpatient variability with a mean difference between observed and target AUC $(0-12 \mathrm{~h})$ of $45 \%(\mathrm{SD} \pm 56 \%)$ in week 1 (Fig. 1). Personalized dose titration resulted in a mean difference between observed and target $\mathrm{AUC}(0-12 \mathrm{~h})$ of $2 \%(\mathrm{SD} \pm$ $32 \%$ ) in week 3 . The difference between week 1 and week 3 showed a trend towards an improved prediction of exposure $(P=0.06)$.

All patients in this phase I study used proton pump inhibitors (PPI) for various reasons, which could decrease sorafenib absorption as a result of an increasing gastric $\mathrm{pH}$. To lower the $\mathrm{pH}$, sorafenib was dissolved in cola, but this did not lead to an increase in sorafenib AUC $(0-12 \mathrm{~h})$ or $C_{\max }$ compared to patients treated with sorafenib dissolved in water $(P=0.24$ and 0.33 , respectively) (Fig. 2).

\section{Treatment efficacy}

Thirteen patients were evaluable for response. As best response, two patients (15\%) had stable disease: a patient with cholangiocarcinoma for a duration of 3 months and treated at the target exposure level of $75-100 \mathrm{mg} / \mathrm{L} / \mathrm{h}$ (sorafenib dose was $2400 \mathrm{mg} /$ week and observed AUC (0-12 h) was $100 \mathrm{mg} / \mathrm{L} / \mathrm{h}$ in week 3$)$ and another patient with hepatocellular carcinoma for a duration of 5.5 months, who was treated at the target exposure level of $100-125 \mathrm{mg} / \mathrm{L} / \mathrm{h}$ (sorafenib dose was $4800 \mathrm{mg} /$ week and observed AUC $(0-12 \mathrm{~h})$ was $94 \mathrm{mg} / \mathrm{L} / \mathrm{h}$ in week 3$)$. The latter patient was previously progressive during treatment with sorafenib at the standard continuously dosed schedule. Eleven patients $(85 \%)$ had progressive disease. No complete or partial responses were observed.

\section{Discussion}

In this phase 1 study, a high-dose, intermittent sorafenib schedule was investigated and dose escalation was performed according to a novel concept, i.e. based on escalating sorafenib plasma $\operatorname{AUC}(0-12$ h) levels, instead of conventional dose escalating cohorts. The aim was to reach the highest tolerable plasma sorafenib peak concentration supposed necessary for the highest intratumoral concentration to improve blockade of tumor kinase targets. With the standard continuous sorafenib schedule of $400 \mathrm{mg}$ twice daily, mean sorafenib exposure varied from $21.8-107 \mathrm{mg} / \mathrm{L} / \mathrm{h}$ on day 1 and $47.8-71.7 \mathrm{mg} / \mathrm{L} / \mathrm{h}$ at steady state, while mean $C_{\max }$ values ranged from $2.9-3-4 \mathrm{mg} / \mathrm{L}$ on day 1 to $5.4-9.4 \mathrm{mg} / \mathrm{L}$ at steady state, which was reached approximately $3 \mathrm{~h}$ after ingestion (range $0-24 \mathrm{~h}$ ) [8, 26]. High-dose pulsatile sorafenib resulted in a $C_{\max }$ up to $21.0 \mathrm{mg} / \mathrm{L}(\mathrm{SD} \pm 11 \mathrm{mg} / \mathrm{L})$, i.e. approximately sevenfold and twofold higher in comparison to a single dose and continuous standard dosing, respectively.

A few other protein kinase inhibitors have been investigated in a high-dose, pulsatile schedule. High-dose erlotinib administered at a dose of $2000 \mathrm{mg}$ per week in NSCLC patients was well tolerated and resulted in a mean overall survival (OS) of 9.5 months [27]. Another phase II study investigated high-dose erlotinib $450 \mathrm{mg}$ every 3 days or the EGFR inhibitor gefitinib $1000 \mathrm{mg}$ every 4 days in patients with known EGFR mutations and disease progression after treatment with conventional dose erlotinib or gefitinib [28]. Treatment was well tolerated and resulted in a median PFS of 6 months in both groups and response rates of 15 and $21 \%$, respectively. In addition, a phase I study escalating the HER2 inhibitor lapatinib in heavily pre-treated patients with HER2-positive breast cancer to $7000 \mathrm{mg}$ on days 1-5 of repeating 14-day cycles showed an objective response rate in $15 \%$ of the patients [29]. We recently investigated the multikinase inhibitor sunitinib in a high-dose, pulsatile phase I study in more than 70 heavily pre-treated patients with advanced solid malignancies [13]. The study showed that a high-pulsatile schedule of 14 times the conventional dose of sunitinib was well tolerated and led to an 18-fold higher $C_{\max }$. In addition, the drug showed promising preliminary efficacy with clinical benefit in $63 \%$ of the patients, including a PFS of $\geq 5$ months in $30 \%$ of the patients and is currently being investigated in two phase II trials (NCT03909724 and NCT03025893). Unfortunately, high-dose, pulsatile sorafenib exposure did not achieve sufficiently increased 
A

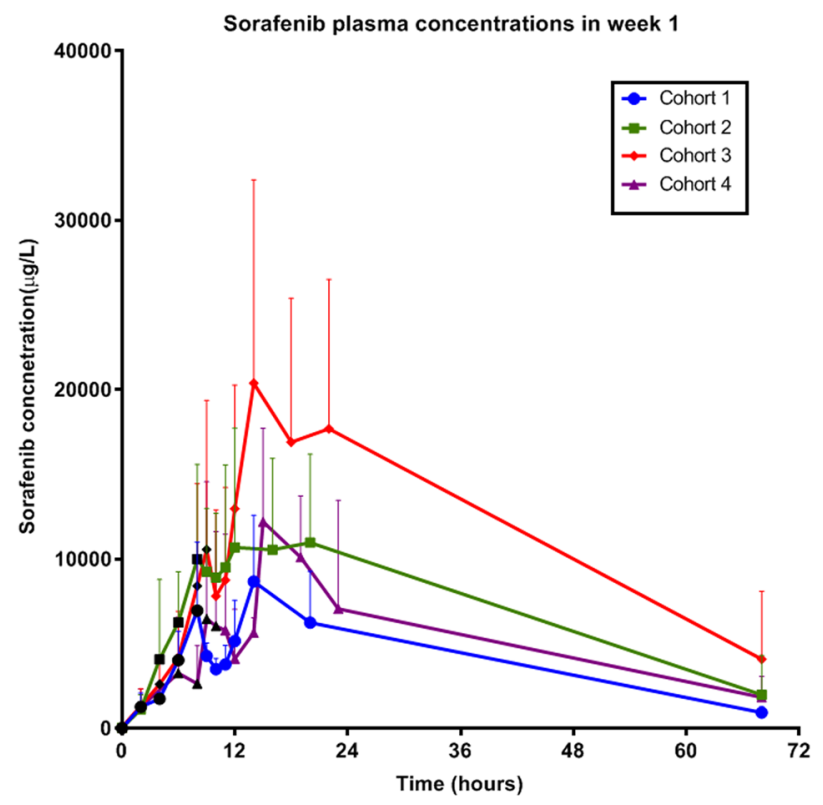

B

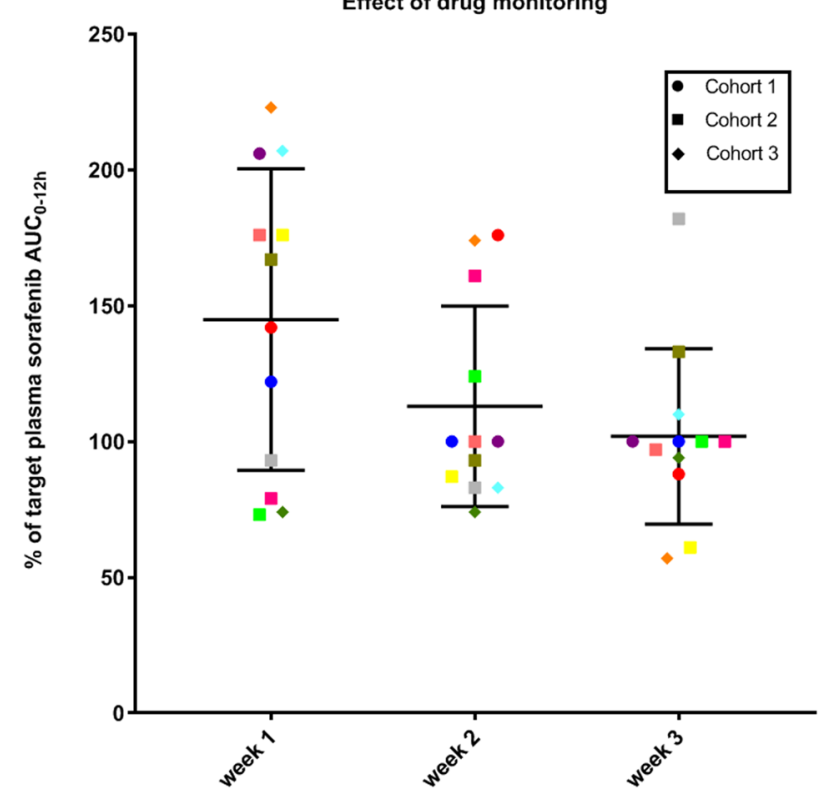

Fig. 1 a High-dose, pulsatile sorafenib plasma concentrations (mean $\pm \mathrm{SD})$ in week 1 using a standard fixed dose for each cohort $(N=$ 17 , black dots are time points of sorafenib ingestion) and $\mathbf{b}$ shows the effect of drug monitoring $(N=12$, each colored symbol represents an individual patient followed in weeks 1-3)

peak concentration levels, which were considered necessary for improved efficacy. With only 3.5 times its conventional dose tolerated in a pulsatile schedule, a peak concentration of only 2 times the standard $\mathrm{C}_{\max }$ was attained in this study. Drug exposure is influenced by its absorption in the stomach which is dependent of factors such as diet and $\mathrm{pH}$. The patients ingested sorafenib with a moderate fat meal and multiple divided doses of 200-400 mg every $2 \mathrm{~h}$, to maximize absorption. This resulted in increased exposure up to sorafenib doses of 2400 once per week, which is 3 times higher than the previously reported saturation $>800 \mathrm{mg}$ sorafenib per day using the standard continuous schedule [15]. Regarding the stomach $\mathrm{pH}$, there have been contradicting results on the effects of PPI on sorafenib absorption, varying from no effects to one-third reduction of sorafenib absorption $[17,18]$. We observed that an acidic beverage such as cola did not improve sorafenib exposure in patients using a PPI. Previously, it was shown that erlotinib bioavailability did improve by cola intake in patients using omeprazole [20]. However, erlotinib is poorly soluble in water, while the maximal aqueous solubility of $0.4 \mathrm{mg} / \mathrm{mL}$ occurs at $\mathrm{pH} \sim 2.0$ [19]. Thus, the absolute differences in solubility for erlotinib dependent on stomach $\mathrm{pH}$ are much higher than for sorafenib, which ranges from $0.013 \mathrm{mg} / 100 \mathrm{~mL}$ at $\mathrm{pH} 4.5$ to $0.034 \mathrm{mg} / 100 \mathrm{~mL}$ at $\mathrm{pH} 1.0$ [17-19].

In this phase 1 study, dose escalation was performed in exposure escalation cohorts, instead of conventional dose escalation cohorts, because sorafenib exposure has large interpatient variability using a fixed dose [8]. Drug monitoring of sorafenib, with a maximum of two dose adjustments, resulted in a difference of $2 \%$ between observed and target AUC $(0-12 \mathrm{~h})$ compared to $45 \%$ at the start of treatment using a fixed dose. Although this was only borderline significant $(P=0.06)$ in this small patient group, the feasibility of sorafenib drug monitoring to achieve a target exposure supports this strategy to improve controlled drug exposure. Further research is necessary to investigate whether dose titration based on exposure will lead to improved efficacy.

Unfortunately, we observed considerable toxicity in this phase 1 study with high-dose, intermittent sorafenib. Grade 5 biliary tract perforation was observed in a patient treated at the target exposure level of $75-100 \mathrm{mg} / \mathrm{L} / \mathrm{h}$ and grade 3 duodenal perforation and grade 5 multiorgan failure in two separate patients treated at target exposure level of $100-125 \mathrm{mg} / \mathrm{L} / \mathrm{h}$. We found that $\geq$ grade 3 toxicity was associated with increased ingested sorafenib dose (doses $\geq 2800 \mathrm{mg} /$ week), but not with plasma sorafenib AUC(0-12 h). Because sorafenib is a multikinase inhibitor, including inhibition of angiogenesis, perforation of the gastrointestinal tract is a well-known side effect, but occurs at a low incidence in $<1 \%$ of the patients treated at the standard continuous schedule [30, 31]. We therefore took precautions to prevent perforations by excluding patients with previous radiotherapy of the thoracic/bowel region, as other studies showed this was a risk factor for gastrointestinal perforation in combination with VEGF inhibitors $[13,32,33]$. Several phase I studies have investigated the safety and pharmacokinetics of standard dose sorafenib and the most important DLTs were skin toxicity, diarrhea and fatigue [23]. However, this was the first study to investigate 
Fig. 2 Effect of cola on sorafenib absorption. Cola did not affect sorafenib AUC $(0-$

12 h) (a) or $C_{\max }$ (b). Black and red dots represent sorafenib dissolved in water and cola, respectively
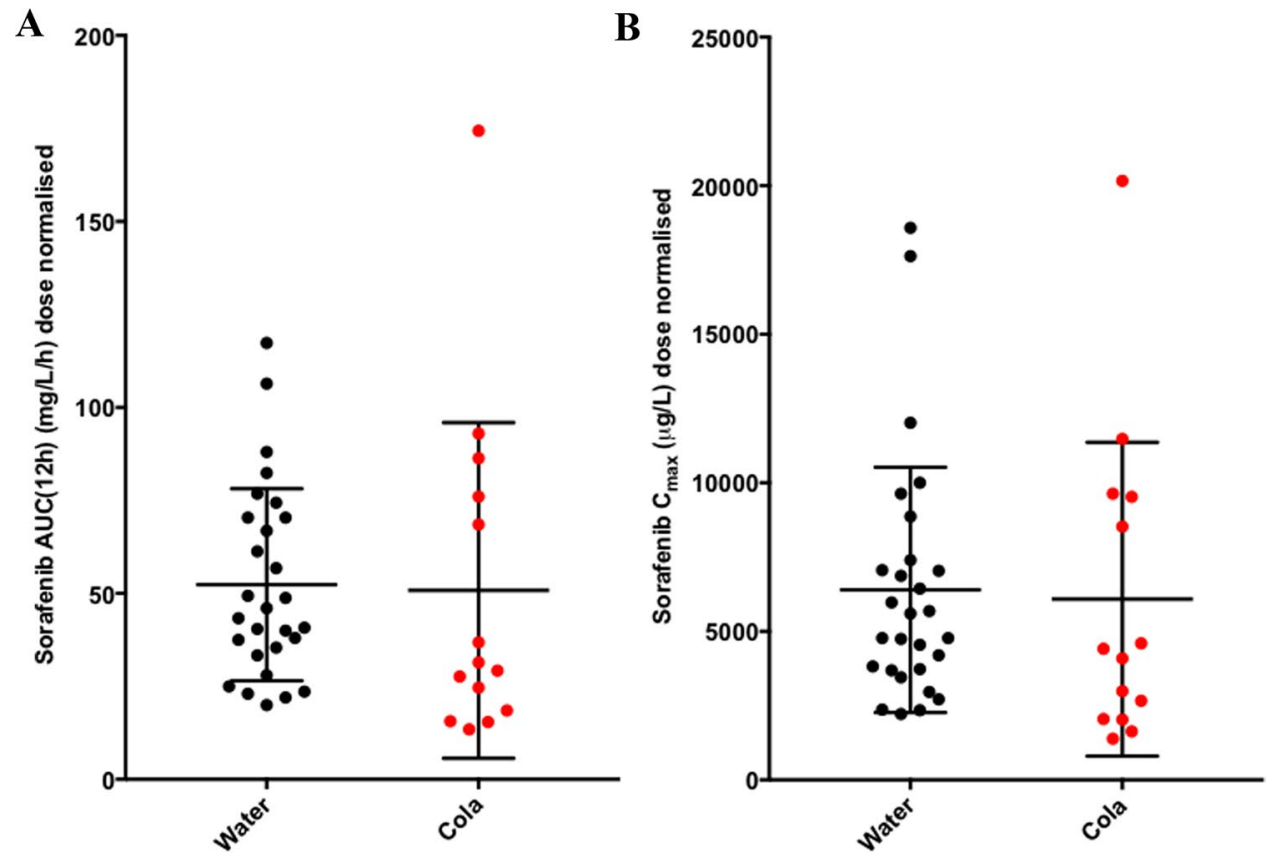

the safety and pharmacokinetics of sorafenib in a high-dose, pulsatile schedule, which showed a different DLT profile. The incidence of perforation was $13 \%$. The frequency and type of serious toxicities (perforation and multiorgan failure) observed at only $\sim 3.5$ times the conventional sorafenib dose in a weekly schedule, were unexpected and reason for preliminary study termination. This was in contrast to the example of high-dose, pulsatile sunitinib, which is also an antiangiogenic drug and showed tolerability comparable to daily administration up to 14 times the conventional dose [13]. A possible explanation may be the enterohepatic circulation of sorafenib. This encompasses the hepatobiliary excretion of sorafenib and a second round of exposure of the intestinal tract to sorafenib with subsequent partial reabsorption. Enterohepatic circulation has been observed in animal models for sorafenib, but not for sunitinib, and is also an explanation for the biphasic plasma concentration time curve typical for sorafenib and observed in the current study [16, 34-37]. In addition, in this pulsatile weekly regimen, sorafenib doses were divided over consecutive 2 -h dose administrations. For instance, a $3600 \mathrm{mg}$ dose was administered as 9 consecutive doses of $400 \mathrm{mg}$, which was done to circumvent the saturable absorption of sorafenib. As a result, local drug concentrations in the GI tract were high during prolonged periods of time and may have caused local anti-angiogenic effects in the GI tract, inducing DLT. The sorafenib dose administered is a better measure of local GI tract sorafenib exposure as opposed to the observed plasma concentrations of sorafenib. This also explains why adverse events were not associated with sorafenib exposure, but rather with sorafenib dose. In contrast to the observed DLT in this study, we only observed mild diarrhea (<grade 3 ) in $27 \%$ of the patients. This may indicate that the anti-angiogenic effects of highdose pulsatile sorafenib were more pronounced than other cytotoxic effects responsible for diarrhea, such as inhibition of the MAPK signaling pathway that can lead to increased chloride secretion by the normal GI mucosa and subsequent secretory diarrhea [38, 39]. While the pulsatile regimen was targeting high exposure (irrespective of dose), the study was discontinued early due to the occurrence of unexpected, serious DLT (despite relatively low plasma exposure). These results may help to guide the future selection of protein kinase inhibitors suitable for an alternative, pulsatile, highdosing schedule.

In conclusion, we have shown the feasibility of drug monitoring to achieve exposure-based treatment cohorts for high-dose, pulsatile sorafenib. Unfortunately, potentially effective high peak concentrations could not be reached due to early toxicity at already lower concentrations than anticipated. Dose escalation above the exposure cohort of $125-150 \mathrm{mg} / \mathrm{L} / \mathrm{h}$ was impossible, so the potential benefit of this alternative approach could not be investigated further.

Acknowledgements we thank the patients who participated in this trial and their families. In addition, we thank Bram Wilhelm of the department of Clinical Pharmacology \& Pharmacy for his contribution to the study.

Funding None declared. 


\section{Compliance with ethical standards}

Conflict of interest The authors declare that they have no conflict of interest.

Ethical approval All procedures performed in studies involving human participants were in accordance with the ethical standards of the institutional committee of the Amsterdam UMC, location VUmc (Medisch Ethische Toetsingscommissie VUmc) and with the 1964 Helsinki Declaration and its later amendments or comparable ethical standards.

Informed consent Informed consent was obtained from all individual participants included in the study.

Open Access This article is licensed under a Creative Commons Attribution 4.0 International License, which permits use, sharing, adaptation, distribution and reproduction in any medium or format, as long as you give appropriate credit to the original author(s) and the source, provide a link to the Creative Commons licence, and indicate if changes were made. The images or other third party material in this article are included in the article's Creative Commons licence, unless indicated otherwise in a credit line to the material. If material is not included in the article's Creative Commons licence and your intended use is not permitted by statutory regulation or exceeds the permitted use, you will need to obtain permission directly from the copyright holder. To view a copy of this licence, visit http://creativecommons.org/licenses/by/4.0/.

\section{References}

1. Wilhelm S, Carter C, Lynch M, Lowinger T, Dumas J, Smith RA et al (2006) Discovery and development of sorafenib: a multikinase inhibitor for treating cancer. Nat Rev Drug Discov 5(10):835-844. https://doi.org/10.1038/nrd2130

2. Wilhelm SM, Adnane L, Newell P, Villanueva A, Llovet JM, Lynch M (2008) Preclinical overview of sorafenib, a multikinase inhibitor that targets both Raf and VEGF and PDGF receptor tyrosine kinase signaling. Mol Cancer Ther 7(10):3129-3140. https://doi.org/10.1158/1535-7163.MCT-08-0013

3. Karaman MW, Herrgard S, Treiber DK, Gallant P, Atteridge CE, Campbell BT et al (2008) A quantitative analysis of kinase inhibitor selectivity. Nat Biotechnol 26(1):127-32. https://doi. org/10.1038/nbt1358 (epub 2008/01/10)

4. Escudier B, Eisen T, Stadler WM, Szczylik C, Oudard S, Staehler M et al (2009) Sorafenib for treatment of renal cell carcinoma: final efficacy and safety results of the phase III treatment approaches in renal cancer global evaluation trial. J Clin Oncol 27(20):3312-3318. https://doi.org/10.1200/JCO.2008.19.5511

5. Llovet JM, Ricci S, Mazzaferro V, Hilgard P, Gane E, Blanc JF et al (2008) Sorafenib in advanced hepatocellular carcinoma. N Engl J Med 359(4):378-390. https://doi.org/10.1056/NEJMo a0708857

6. Brose MS, Nutting CM, Jarzab B, Elisei R, Siena S, Bastholt $\mathrm{L}$ et al (2014) Sorafenib in radioactive iodine-refractory, locally advanced or metastatic differentiated thyroid cancer: a randomised, double-blind, phase 3 trial. Lancet 384(9940):319-328. https://doi.org/10.1016/S0140-6736(14)60421-9

7. Kim JE, Ryoo BY, Ryu MH, Chang HM, Suh DJ, Lee HC et al (2011) Sorafenib for hepatocellular carcinoma according to Child-Pugh class of liver function. Cancer Chemother Pharmacol 68(5):1285-90. https://doi.org/10.1007/s00280-011-1616-x (epub 2011/03/30)
8. Strumberg D, Richly H, Hilger RA, Schleucher N, Korfee S, Tewes $M$ et al (2005) Phase I clinical and pharmacokinetic study of the Novel Raf kinase and vascular endothelial growth factor receptor inhibitor BAY 43-9006 in patients with advanced refractory solid tumors. J Clin Oncol 23(5):965-972. https://doi. org/10.1200/JCO.2005.06.124

9. Escudier B, Szczylik C, Hutson TE, Demkow T, Staehler M, Rolland F et al (2009) Randomized phase II trial of first-line treatment with sorafenib versus interferon Alfa-2a in patients with metastatic renal cell carcinoma. J Clin Oncol 27(8):1280-1289. https://doi.org/10.1200/JCO.2008.19.3342

10. Pecuchet N, Lebbe C, Mir O, Billemont B, Blanchet B, Franck $\mathrm{N}$ et al (2012) Sorafenib in advanced melanoma: a critical role for pharmacokinetics? Br J Cancer 107(3):455-461. https://doi. org/10.1038/bjc.2012.287

11. Rovithi M, Verheul HMW (2017) Pulsatile high-dose treatment with antiangiogenic tyrosine kinase inhibitors improves clinical antitumor activity. Angiogenesis 20(3):287-289. https://doi. org/10.1007/s10456-017-9555-8

12. Rovithi M, de Haas RR, Honeywell RJ, Poel D, Peters GJ, Griffioen AW et al (2016) Alternative scheduling of pulsatile, high dose sunitinib efficiently suppresses tumor growth. J Exp Clin Cancer Res 35(1):138. https://doi.org/10.1186/s13046-016-0411-2

13. Rovithi M, Gerritse SL, Honeywell RJ, Ten Tije AJ, Ruijter R, Peters GJ et al (2018) Phase I dose-escalation study of once weekly or once every two weeks administration of high-dose sunitinib in patients with refractory solid tumors. J Clin Oncol. https ://doi.org/10.1200/JCO.18.00725

14. Wang X, Zhang L, Goldberg SN, Bhasin M, Brown V, Alsop DC et al (2011) High dose intermittent sorafenib shows improved efficacy over conventional continuous dose in renal cell carcinoma. J Transl Med 9:220. https://doi.org/10.1186/1479-5876-9-220

15. Hornecker M, Blanchet B, Billemont B, Sassi H, Ropert S, Taieb $F$ et al (2012) Saturable absorption of sorafenib in patients with solid tumors: a population model. Invest New Drugs 30(5):19912000. https://doi.org/10.1007/s10637-011-9760-z

16. (Nexavar) UFaDAS (2005) Clinical pharmacology and biopharmaceutics review

17. Lalani AA, McKay RR, Lin X, Simantov R, Kaymakcalan MD, Choueiri TK (2017) Proton pump inhibitors and survival outcomes in patients with metastatic renal cell carcinoma. Clin Genitourin Cancer 15(6):724-732. https://doi.org/10.1016/j. clgc.2017.05.019

18. Lind JS, Dingemans AM, Groen HJ, Thunnissen FB, Bekers O, Heideman DA et al (2010) A multicenter phase II study of erlotinib and sorafenib in chemotherapy-naive patients with advanced non-small cell lung cancer. Clin Cancer Res 16(11):3078-3087. https://doi.org/10.1158/1078-0432.CCR-09-3033

19. Budha NR, Frymoyer A, Smelick GS, Jin JY, Yago MR, Dresser MJ et al (2012) Drug absorption interactions between oral targeted anticancer agents and PPIs: is pH-dependent solubility the Achilles heel of targeted therapy? Clin Pharmacol Ther 92(2):203-213. https://doi.org/10.1038/clpt.2012.73

20. van Leeuwen RW, Peric R, Hussaarts KG, Kienhuis E, NS IJ, de Bruijn $P$ et al (2016) Influence of the acidic beverage cola on the absorption of erlotinib in patients with non-small-cell lung cancer. J Clin Oncol 34(12):1309-1314. https://doi.org/10.1200/ JCO.2015.65.2560 (epub 2016/02/10)

21. Retamero A, Conde-Estevez D (2017) Erlotinib and acid suppressive agents: is it worth to take a coke? Ann Oncol 28(1):192-193. https://doi.org/10.1093/annonc/mdw530 (epub 2017/02/09)

22. Widmer N, Bardin C, Chatelut E, Paci A, Beijnen J, Leveque D et al (2014) Review of therapeutic drug monitoring of anticancer drugs part two-targeted therapies. Eur J Cancer 50(12):2020 2036. https://doi.org/10.1016/j.ejca.2014.04.015 (epub 2014/06/15) 
23. Strumberg D, Clark JW, Awada A, Moore MJ, Richly H, Hendlisz A et al (2007) Safety, pharmacokinetics, and preliminary antitumor activity of sorafenib: a review of four phase I trials in patients with advanced refractory solid tumors. Oncologist 12(4):426-437. https://doi.org/10.1634/theoncologist.12-4-426

24. Schwartz LH, Seymour L, Litiere S, Ford R, Gwyther S, Mandrekar $S$ et al (2016) RECIST 1.1-standardisation and diseasespecific adaptations: perspectives from the RECIST Working Group. Eur J Cancer 62:138-145. https://doi.org/10.1016/j. ejca.2016.03.082

25. Honeywell R, Yarzadah K, Giovannetti E, Losekoot N, Smit EF, Walraven $M$ et al (2010) Simple and selective method for the determination of various tyrosine kinase inhibitors used in the clinical setting by liquid chromatography tandem mass spectrometry. J Chromatogr B Anal Technol Biomed Life Sci 878(1516):1059-1068. https://doi.org/10.1016/j.jchromb.2010.03.010

26. European Medicines Agency (EMA) (2006) Nexavar: European Public Assessment Reports (EPAR)-scientific discussion. https ://www.ema.europa.eu/en/documents/scientific-discussion/nexav ar-epar-scientific-discussion_en.pdf. Accessed 2 June 2019

27. Milton DT, Azzoli CG, Heelan RT, Venkatraman E, Gomez JE, Kris MG et al (2006) A phase I/II study of weekly high-dose erlotinib in previously treated patients with nonsmall cell lung cancer. Cancer 107(5):1034-1041. https://doi.org/10.1002/cncr.22088

28. Zhu Y, Du Y, Liu H, Ma T, Shen Y, Pan Y (2016) Study of efficacy and safety of pulsatile administration of high-dose gefitinib or erlotinib for advanced non-small cell lung cancer patients with secondary drug resistance: a single center, single arm, phase II clinical trial. Thorac Cancer 7(6):663-669. https://doi. org/10.1111/1759-7714.12384

29. Chien AJ, Munster PN, Melisko ME, Rugo HS, Park JW, Goga A et al (2014) Phase I dose-escalation study of 5-day intermittent oral lapatinib therapy in patients with human epidermal growth factor receptor 2-overexpressing breast cancer. J Clin Oncol 32(14):1472-1479. https://doi.org/10.1200/JCO.2013.52.1161

30. EMA (2018) European Public Assessment Report-product information. NEXAVAR ${ }^{\circledR}$ sorafenib. EMA, London. https://www.ema. europa.eu/documents/product-information/nexavar-epar-productinformation_en.pdf. Accessed 26 Jul 2018

31. Gyawali B, Shimokata T, Ando M, Honda K, Ando Y (2016) Risk of serious adverse events and fatal adverse events with sorafenib in patients with solid cancer: a meta-analysis of phase 3 randomized controlled trialsdagger. Ann Oncol 28(2):246-253. https ://doi.org/10.1093/annonc/mdw549 (epub 2016/10/25)
32. Murray L, Longo J, Wan J, Chung C, Wang L, Dawson L et al (2017) Phase I dose escalation study of concurrent palliative radiation therapy with sorafenib in three anatomical cohorts (thorax, abdomen, pelvis): the TAP study. Radiother Oncol 124(1):74-79. https://doi.org/10.1016/j.radonc.2017.06.007

33. Lee MO, Song SH, Jung S, Hur S, Asahara T, Kim H et al (2012) Effect of ionizing radiation induced damage of endothelial progenitor cells in vascular regeneration. Arterioscler Thromb Vasc Biol 32(2):343-352. https://doi.org/10.1161/ATVBAHA.111.237651

34. Abbiati RA, Manca D (2017) Enterohepatic circulation effect in physiologically based pharmacokinetic models: the sorafenib case. Ind Eng Chem Res 56(12):3156-3166. https://doi.org/10.1021/ acs.iecr.6b03686

35. Abbiati RA, Manca D (2017) Innovations and improvements in pharmacokinetic models based on physiology. Curr Drug Deliv 14(2):190-202. https://doi.org/10.2174/15672018136661605241 42031

36. Haznedar JÖ, Patyna S, Bello CL, Peng GW, Speed W, Yu X et al (2009) Single- and multiple-dose disposition kinetics of sunitinib malate, a multitargeted receptor tyrosine kinase inhibitor: comparative plasma kinetics in non-clinical species. Cancer Chemother Pharmacol 64(4):691-706. https://doi.org/10.1007/s0028 0-008-0917-1

37. Edginton AN, Zimmerman EI, Vasilyeva A, Baker SD, Panetta JC (2016) Sorafenib metabolism, transport, and enterohepatic recycling: physiologically based modeling and simulation in mice. Cancer Chemother Pharmacol 77(5):1039-1052. https://doi. org/10.1007/s00280-016-3018-6 (epub 2016/04/08)

38. Keely SJ, Barrett KE (2003) p38 mitogen-activated protein kinase inhibits calcium-dependent chloride secretion in T84 colonic epithelial cells. Am J Physiol Cell Physiol 284(2):C339-C348. https ://doi.org/10.1152/ajpcell.00144.2002 (epub 2002/10/22)

39. Heinzerling L, Eigentler TK, Fluck M, Hassel JC, Heller-Schenck D, Leipe J et al (2019) Tolerability of BRAF/MEK inhibitor combinations: adverse event evaluation and management. ESMO Open 4(3):e000491. https://doi.org/10.1136/esmoopen-2019000491 (epub 2019/06/25)

Publisher's Note Springer Nature remains neutral with regard to jurisdictional claims in published maps and institutional affiliations. 